\title{
Screening for severe combined immunodeficiency in neonates
}

This article was published in the following Dove Press journal:

Clinical Epidemiology

13 September 2013

Number of times this article has been viewed

\author{
Brian T Kelly' \\ Jonathan S Tam' \\ James W Verbsky ${ }^{1,2}$ \\ John M Routes ${ }^{1,2}$ \\ 'Department of Pediatrics, \\ 2Department of Microbiology and \\ Molecular Genetics, Medical College \\ of Wisconsin, Milwaukee, WI, USA
}

Correspondence: John M Routes

9000 West Wisconsin Avenue,

Suite 440, Milwaukee, WI 53226, USA

Tel + I 4142666840

Fax + I 4|4266 6437

Email jroutes@mcw.edu

\begin{abstract}
Severe combined immunodeficiency (SCID) is a rare disease that severely affects the cellular and humoral immune systems. Patients with SCID present with recurrent or severe infections and often with chronic diarrhea and failure to thrive. The disease is uniformly fatal, making early diagnosis essential. Definitive treatment is hematopoietic stem cell transplantation, with best outcomes prior to 3.5 months of age. Newborn screening for SCID using the T-cell receptor excision circle assay has revolutionized early identification of infants with SCID or severe T-cell lymphopenia.
\end{abstract}

Keywords: severe combined immunodeficiency, T-cell receptor excision circle, newborn screening, primary immunodeficiency

\section{Introduction}

Severe combined immunodeficiency (SCID) is a primary immunodeficiency (PID) resulting from heritable defects of the cellular and humoral immune system. A variety of mutations that affect the function and development of T-cells may cause an SCID phenotype. Regardless of the molecular cause, SCID is commonly characterized by a severe deficiency in naïve T-cells. ${ }^{1-3}$ Infants born with SCID typically appear normal at birth, but are at high risk of serious infections after waning of maternal antibody. If untreated, SCID has $100 \%$ mortality. Treatment is generally hematopoietic stem cell transplantation (HSCT), although gene therapy has been successfully used in some forms of SCID. Early definitive treatment, before the onset of infection, results in the best outcomes. ${ }^{1-5}$

Because early diagnosis of SCID is critical, detection of SCID through newborn screening (NBS) is the ideal approach. The T-cell receptor excision circle (TREC) assay, which can be performed along with other NBS tests, has transformed the early diagnosis of SCID and is being implemented in several states across the United States. ${ }^{6}$ Wisconsin was the first state to implement NBS for SCID, in January 2008, using the TREC assay, and there have been no reported cases of SCID in Wisconsin that were not identified by NBS. ${ }^{7,8}$ In this review, we will describe the epidemiology, diagnosis, and treatment of SCID, but also how NBS has affected how we view the disease.

\section{Epidemiology of SCID}

The incidence of SCID has historically been considered to be approximately one in 100,000 births. ${ }^{5,9}$ However, many experts believe this number likely underestimates the true incidence of SCID, as many patients may have died prior to diagnosis in the era 
before screening. Some countries have established registries to monitor rates of immune deficiency, ranging from one in 26,000 in Costa Rica to one in 78,000 in Chile. ${ }^{10,11}$ The incidence of SCID is highest in regions where consanguineous marriage is common. For example, in Saudi Arabia, one in 5,000 births result in SCID. ${ }^{12}$ There have been no prevalence studies performed in the United States; however, since the implementation of NBS for SCID, the true incidence is becoming better understood. ${ }^{6,13-16}$

SCID is a syndrome that is caused by mutations in any one of at least ten genes that result in aberrant development of naïve T-cells. ${ }^{3}$ SCID is typically classified by which lymphocyte subsets (T-cells, B-cells, NK [natural killer]-cells) are affected (Table 1). ${ }^{3,17,18}$ Approximately half of all cases of SCID are X-linked, and are due to mutations in interleukin (IL)-2 receptor gamma chain (IL-2R $\gamma$ ) gene. IL-2R $\gamma$ is shared by the receptors for IL-2, IL-4, IL-7, IL-9, IL-15, and IL-21, and is required for ligand-induced signaling.

The most common cause of autosomal recessive SCID are mutations in the adenosine deaminase (ADA) gene leading to ADA deficiency, which represents approximately $15 \%$ of all SCID patients. ${ }^{3}$ ADA metabolizes adenosine and

Table I Identified gene mutations in severe combined immunodeficiency defined by lymphocyte population

\begin{tabular}{|c|c|c|c|}
\hline $\begin{array}{l}\text { Lymphocyte } \\
\text { population }\end{array}$ & Disease & Gene & $\begin{array}{l}\% \text { of } \\
\text { cases }\end{array}$ \\
\hline \multirow[t]{8}{*}{$\mathrm{T}-\mathrm{B}+\mathrm{NK}+$} & IL-7R $\alpha$ chain & IL7RA & 10 \\
\hline & CD3 $\delta$ deficiency & $C D 3 D$ & \\
\hline & $\mathrm{CD} 3 \varepsilon$ deficiency & $C D 3 E$ & \\
\hline & $\mathrm{CD} 3 \zeta$ deficiency & $C D 3 Z$ & \\
\hline & CD45 deficiency & PTPRC & \\
\hline & ZAP70 deficiency & ZAP79 & \\
\hline & CD25 deficiency & IL2RA & \\
\hline & $\begin{array}{l}\text { Actin-regulating protein coronin } \\
\text { IA deficiency }\end{array}$ & COROIA & \\
\hline \multirow[t]{2}{*}{$\mathrm{T}-\mathrm{B}+\mathrm{NK}-$} & Common $\gamma$ chain deficiency & $\operatorname{IL} 2 R G^{a}$ & 50 \\
\hline & Janus kinase 3 deficiency & JAK3 & 6.5 \\
\hline \multirow[t]{6}{*}{$\mathrm{T}-\mathrm{B}-\mathrm{NK}+$} & $\begin{array}{l}\text { Recombinase activating gene I } \\
\text { deficiency }\end{array}$ & RAGI & 3 \\
\hline & $\begin{array}{l}\text { Recombinase activating gene } 2 \\
\text { deficiency }\end{array}$ & RAG2 & 3 \\
\hline & Artemis deficiency & DCLREIC & \\
\hline & DNA ligase IV deficiency & LIG4 & \\
\hline & Cernunnos deficiency & NHEJI & \\
\hline & $\begin{array}{l}\text { DNA protein kinase catalytic } \\
\text { subunit deficiency }\end{array}$ & PRKDC & \\
\hline \multirow[t]{3}{*}{$\mathrm{T}-\mathrm{B}-\mathrm{BK}-$} & Adenosine deaminase deficiency & $A D A$ & 15 \\
\hline & $\begin{array}{l}\text { Purine nucleoside phosphorylase } \\
\text { deficiency }\end{array}$ & PNP & \\
\hline & Reticular dysgenesis & $A K 2$ & \\
\hline
\end{tabular}

Notes: a'X-linked disease. Data from ${ }^{2,17,18}$.

Abbreviations: B, B-cell; IL, interleukin; NK, natural killer cell; T, T-cell. deoxyadenosine, thereby preventing their toxic accumulation in lymphocytes. An absence of ADA leads to the accumulation of adenosine and deoxyadenosine, leading to the death of T-cells, B-cells, and NK-cells. ${ }^{19}$

Defects in IL-7R $\alpha$ chain (also known as CD127) comprise approximately $10 \%$ of all cases of SCID, making it the third most common form of SCID. ${ }^{3}$ The IL-7R $\alpha$ chain plays a critical role in T-cell development. ${ }^{20} \mathrm{~A}$ mutation in the Janus kinase 3 (JAK3) gene makes up $6.5 \%$ of SCID cases. ${ }^{3}$ JAK3 associates with IL-2R $\gamma$ and its absence leads to signaling defects similar to mutations in IL-2R $\gamma^{21,22}$ Mutations in the recombinase activating genes 1 and 2 (RAG1 and RAG2) account for approximately $3 \%$ of cases. ${ }^{3}$ Mutations in RAG1 or RAG2 result in the blocking of T- and B-cell development secondary to the inability to initiate recombination of the DNAs variable, diversity, and joining regions, and thereby do not form functional T-cell or B-cell receptors. ${ }^{23,24}$ A deficiency in Artemis, or DNA cross-link repair 1C gene (DCLRE1C), results in an inability to repair DNA after cuts have been made by RAG1 or RAG2. Thus, like RAG1 and RAG2, it results in another form of T-B-NK+ SCID. This deficiency is found predominantly in Athabascan-speaking Native Americans, specifically the Navajo and Apache, and is a prime example of a form of SCID with an ethnic predilection. While, in the general population, Artemis may comprise only around $1 \%$ of cases of SCID, the incidence in these populations is as high as 52 in 100,000 births. ${ }^{25}$ The molecular cause for SCID is unknown in approximately $10 \%$ of cases. ${ }^{26}$

Hypomorphic mutations in genes that cause SCID can lead to Omenn Syndrome (OS). OS has also been termed "leaky SCID" and has clinical features that are distinct from classical SCID, such as severe skin disease (erythroderma, desquamation, and dermatitis), lymphadenopathy, hepatosplenomegaly, and high immunoglobulin (Ig)E levels. These clinical features are secondary to expansion of oligoclonal autoreactive T-cells, predominantly TH (T helper)2-type T-cells. ${ }^{27}$

\section{Clinical manifestations of SCID}

The classic symptoms of SCID are recurrent severe infections, chronic diarrhea, and failure to thrive. ${ }^{28}$ The presentation of SCID may vary, reflecting the diverse molecular causes of SCID and the fact that some mutations, termed hypomorphic mutations, code for proteins with a reduced but not absent function. ${ }^{29}$ Affected infants generally appear well at birth, but develop frequent episodes of diarrhea, pneumonia, otitis, sepsis, and cutaneous infections within the first few months of life. Growth may appear normal initially, but extreme wasting usually develops after diarrhea 
and infections begin. Increased resting energy expenditure is also more common in SCID patients with failure to thrive and may contribute to its development. ${ }^{30}$

Persistent respiratory tract infection is common, with failure to clear viruses leading to persistent bronchiolitis. Infections with common viral pathogens, such as adenovirus, cytomegalovirus, Epstein-Barr virus, rotavirus, norovirus, respiratory syncytial virus, varicella zoster, herpes simplex virus, influenza, and parainfluenza 3, are often fatal. Bacterial infections are less common in part because of the presence of maternal $\mathrm{IgG}$ in early infancy. However, prolonged otitis media and invasive bacterial infections, such as staphylococcal septicemia and pneumonia, occur and may respond poorly to appropriate treatment. Patients also present with opportunistic infections, such as pneumonia due to Pneumocystis jirovecii. Severe invasive fungal infection is rare, but often fatal. On the other hand, extensive persistent mucocutaneous candidiasis is common. Attenuated vaccine organisms, such as oral polio vaccine virus, rotavirus, varicella, and Bacillus Calmette-Guérin, may cause severe or fatal disease. ${ }^{31}$

Children with SCID may also suffer from graft-versushost disease (GVHD), as they lack the ability to reject foreign tissue. GVHD may result from alloreactive maternal T-cells that cross into the fetal circulation in utero or from $\mathrm{T}$ lymphocytes in nonirradiated blood products. ${ }^{3}$

\section{Screening for SCID}

In order to be considered for NBS, a disease must meet several criteria first developed by Wilson and Jungner in the 1960s (Table 2). ${ }^{32}$ It should be noted that meeting the criteria for NBS does not necessarily mean the disease will be added to the Recommended Uniform Screening Panel of recommended tests by the United States Government. There are other considerations, including economic and political considerations, as well as practical considerations (eg, has the assay been shown to be sensitive, specific, and have a low false positive rate using NBS cards) that factor into the decision for recommending new assays for NBS.

Prior to the TREC assay, the complete blood count with differential was the best available initial screening test for

Table 2 Wilson and Jungner criteria for population-based newborn screening

Incidence of disease merits newborn screening

Disease is not easily identified through physical examination

Disease must result in severe clinical manifestations

Prognosis improves with early diagnosis and treatment

Available, economic, sensitive, and specific screening test

Note: Data from ${ }^{32}$
SCID. While often overlooked, an absolute lymphocyte count of less than $3,000 \mathrm{c} / \mathrm{mm}^{3}$ should trigger suspicion of SCID. ${ }^{33,34}$ Unfortunately, the complete blood count is neither sensitive nor specific for SCID. ${ }^{33}$ Assays to detect other biomarkers of T-cell lymphopenia (high IL-7 levels or low CD3 protein levels) have been proposed but not validated using NBS cards. ${ }^{35-37}$

In 2005, Chan and Puck reported on the use of the TREC assay as a possible population-based NBS assay to detect SCID. ${ }^{38}$ TRECs are small pieces of circular DNA that are formed during T-cell rearrangement in the thymus that result in the generation of functional T-cells. One specific TREC $(\delta \mathrm{Rec}-\Psi \mathrm{J} \alpha)$ is generated in approximately $70 \%$ of T-cells that express the $\alpha \beta$ T-cell receptor, which is the most common T-cell in the periphery. ${ }^{13,14,38}$ The TREC assay enumerates the number of $\delta$ Rec- $\Psi J \alpha$ TRECs by real-time (RT-q) polymerase chain reaction (PCR) from DNA eluted from dried blood spots on an NBS card. Because TRECs do not replicate with cell division, the TREC assay is a biomarker for the number of naïve T-cells that have recently emerged from the thymus. As naïve T-cells are reduced in all forms of SCID, the TREC assay should identify infants with SCID regardless of molecular defect. Confirmation of the diagnosis of SCID is performed by enumerating the number of naïve T-cells in the blood by flow cytometry.

Wisconsin, in 2008, became the first state in the US to screen all of its neonates with the TREC assay. ${ }^{15,39}$ During the first 3 years of NBS in Wisconsin, 207,696 infants were screened, of whom $0.035 \%$ had an abnormal screen. Normal T-cell counts were found in $53 \%$ of the abnormal results, and the remainder of infants had varying levels of T-cell lymphopenia. The sensitivity (100\%), specificity (99.98\%), and positive predictive value (45.83\%) were remarkable for an NBS test. Of the patients with severe T-cell lymphopenia (sTCL) identified by the TREC assay, 58\% had secondary causes (eg, congenital anomaly, lymphatic abnormality, chromosomal abnormality, or metabolic disorder), 15\% had reversible T-cell lymphopenia, $12 \%$ with $22 q 11$ deletion, and $15 \%$ SCID/sTCL. Of the five patients with SCID/sTCL, three patients had successful HSCT, one is receiving ADA replacement, and one infant is awaiting $\mathrm{HSCT}^{8,40}$ Interestingly, the first patient identified by NBS was an infant who presented with frequent abscesses and ultimately was found to have a dominant negative mutation in the RAC2 gene, which was previously thought to be associated solely with neutrophil dysfunction. ${ }^{41}$ In summary, the TREC assay for NBS for SCID in Wisconsin has been shown to be a highly sensitive and specific screening test for sTCL with an extremely low false positive rate. ${ }^{15,42,43}$ 
There are differences among US states as to how the TREC assay is performed. Some states initially measure the number of TRECs alone by RT-qPCR, and further testing is performed only if the number of TRECs is low. DNA template integrity is then checked by performing RT-qPCR on a housekeeping gene ( $\beta$-actin or RNAseP [Ribonuclease $\mathrm{P}])^{40}$ In contrast, other states measure TRECs and check for DNA template integrity at the same time. ${ }^{42}$ Regardless of the differences in the approach, the sensitivity and specificity of the TREC assay remains extraordinary. Each state has devised its own screening algorithm, resulting in great variability among their protocols. For example, there is significant variation among states in their assessment of the presence and integrity of DNA on the provided blood samples. The screening laboratories in California, Pennsylvania, and Wisconsin amplify a control gene, in this case $\beta$-actin, along with the $\delta \operatorname{Rec}-\Psi \mathrm{J} \alpha$ TREC only if there are abnormal or inconclusive numbers of TRECs; $98.4 \%$ of samples collected did not require followup testing with $\beta$-actin control. ${ }^{40}$ In Massachusetts, New York, and Texas, screening laboratories have amplified the $\delta$ Rec- $\Psi$ J $\alpha$ TREC simultaneously with another control gene, ribonuclease $\mathrm{P}$ (RNAseP). ${ }^{42}$

The TREC assay has not been without its challenges. Premature infants (gestational age less than 37 weeks at birth) present as a unique problem in the use of the TREC assay as they show a much higher false positive rate compared to full-term infants. ${ }^{15,40,44}$ There are several factors that may lead to false positive assays in these infants. T-cells populate the periphery in the third trimester, thus low T-cell counts could be physiologic normal process in severe prematurity. There is a lack of data on normal TREC counts as a function of gestational age. Further, many premature infants receive prenatal medications, especially corticosteroids, for lung maturation, which have been implicated in reduction of circulating T-cells. ${ }^{45}$ Diluted samples obtained from indwelling catheters may have been spotted on the NBS card, or the presence of substances (eg, heparin or chelating agents) in the blood that interfere with the PCR assay could also affect the results of the TREC assay. ${ }^{46}$ Accetta et al reviewed the medical records of 39 infants with abnormal or inconclusive TREC assays who passed away prior to further assessment during the first 2 years of screening in Wisconsin. Many of these infants were less than 33 weeks gestational age and died secondary to congenital abnormalities, prematurity, or pregnancy complications. No infants were identified who had a probable diagnosis of SCID. ${ }^{44}$ Due to the high incidence of false positive TREC assays in premature infants, Wisconsin repeats the TREC assay in premature infants when they reach an adjusted gestational age of 37 weeks. However, it is possible that a premature infant may have SCID, which has been reported, ${ }^{47}$ and premature infants should be followed until their T-cell counts normalize or a cause of their lymphopenia is ascertained.

In patients with OS, there may be an associated T-cell lymphocytosis secondary to the expansion of oligoclonal T-cells, which are $\mathrm{CD} 45 \mathrm{RO}+$ (memory T-cells). However, because TRECs do not replicate with cellular division, the number of TRECs in OS are reduced. ${ }^{39} \mathrm{~A}$ similar situation occurs in babies with SCID who have maternal engraftment. ${ }^{48}$

\section{Diagnosis of SCID}

The patient suspected of having SCID requires evaluation of both humoral and cellular immunity. Flow cytometric immunophenotyping of lymphocyte subsets in peripheral blood is important in patients suspected of having SCID. ${ }^{1}$ Enumeration of naïve T-cells in the peripheral blood as well as NK-cells and B-cells by flow cytometry is essential in the diagnosis of SCID. All forms of SCID are characterized by a severe deficiency in naïve T-cells $\left(<200 \mathrm{~T}-\right.$ cells $\left./ \mathrm{mm}^{3}\right)$. Assessing T-cell function is essential as well and is determined by the in vitro measurement of responses to mitogens, such as phytohemagglutinin (PHA) and concanavalin A (ConA). In SCID, the T-cell response to mitogens is $<5 \%$ of normal T-cell responses. The pattern of abnormality (ie, if NK-cells and B-cell numbers are low or normal) may also help to identify or narrow down the possible genetic defect leading to SCID. Evaluation of humoral immunity may include measurement of Ig levels, but must also be interpreted in context of the patient's age. ${ }^{49}$ While not necessary for the decision to perform HSCT, efforts should be made to establish a molecular diagnosis for the cause of SCID.

\section{Treatment of SCID}

HSCT is the gold-standard treatment for SCID. ${ }^{3,26,50,51}$ HSCT reconstitutes a functional immune system and is lifesaving. Evidence has shown that early HSCT (at less than 3.5 months of age) results in significant improvement in survival after transplant. In a study from a single center, the eight year Kaplan-Meier survival curve improved from $70 \%$ to $96 \%$ in infants who had an HSCT less than 3.5 months after birth. ${ }^{52}$ With the advent of NBS for SCID, patients with SCID are detected earlier and transplantation is occurring earlier. ${ }^{7,84}$ While awaiting HSCT, patients with SCID receive a prophylaxis regimen designed to prevent opportunistic bacterial, fungal, and viral infection (Table 3). Infants with SCID are not administered live vaccines, which would cause clinical 
Table 3 Recommended infectious disease prophylaxis for newborns suspected of having SCID

\begin{tabular}{|c|c|c|c|c|}
\hline Prophylaxis & Drug (dose) & Time of Initiation & Alternatives & Comments \\
\hline \multicolumn{5}{|l|}{ In newborns } \\
\hline PCP & $\begin{array}{l}\text { Oral TMP-SMX ( } 5 \mathrm{mg} \text { TMP/kg } \\
\text { once a day for } 2 \text { consecutive } \\
\text { days weekly) }\end{array}$ & I mo old & $\begin{array}{l}\text { Oral atovaquone } \\
(30 \mathrm{mg} / \mathrm{kg} \text { once } \\
\text { a day) }\end{array}$ & $\begin{array}{l}\text { Verify that bilirubin is }<2 \text { times the upper } \\
\text { limit of normal before starting; monitor ALT } \\
\text { and AST every } 2-4 \mathrm{wk}\end{array}$ \\
\hline HSV and VSV & $\begin{array}{l}\text { Oral acyclovir ( } 20 \mathrm{mg} / \mathrm{kg} \text { per } \\
\text { dose } 3 \text { times a day) }\end{array}$ & At first visit & & \\
\hline RSV & $\begin{array}{l}\text { Palivizumab ( } 15 \mathrm{mg} / \mathrm{kg} \\
\text { administered intramuscularly) }\end{array}$ & I mo old & & $\begin{array}{l}\text { Given during peak RSV season, typically } \\
\text { November-March }\end{array}$ \\
\hline $\begin{array}{l}\text { General } \\
\text { (bacterial/viral) }\end{array}$ & IVIG (0.4-0.5 g/kg every month) & I mo old & & $\begin{array}{l}\text { Monitor troughs monthly and maintain } \\
\text { immunoglobulin }>600 \mathrm{mg} / \mathrm{dL}\end{array}$ \\
\hline Fungal & Fluconazole (6 mg/kg once daily) & I mo old & Micafungin & Follow AST and ALT every $2-4$ wk \\
\hline \multicolumn{5}{|c|}{ In family members or close contacts } \\
\hline Influenza & $\begin{array}{l}\text { Inactivated or attenuated } \\
\text { influenza vaccine }\end{array}$ & Seasonally & & $\begin{array}{l}\text { Attenuated vaccine safe in family members } \\
\text { of infant with SCID }\end{array}$ \\
\hline Pertussis & Tdap vaccine & $\begin{array}{l}\text { Per routine childhood } \\
\text { vaccinations }\end{array}$ & & $\begin{array}{l}\text { One booster for adolescents ( } 1 \mathrm{I}-12 \text { y old), } \\
\text { adults } 19-64 \text { y old, and adults }>65 \text { y old }\end{array}$ \\
\hline
\end{tabular}

Note: Reprinted from The Journal of Allergy and Clinical Epidemiology, 129, James Verbsky, Monica Thakar, John Routes, The Wisconsin approach to newborn screening for severe combined immunodeficiency, 622-627, Copyright 2012, with permission from Elsevier. ${ }^{7}$

Abbreviations: ALT, alanine aminotransferase; AST, aspartate aminotransferase; HSV, herpes simplex virus; IVIG, intravenous immunoglobulin; mo,month; PCP, Pneumocystis carinii pneumonia; RSV, respiratory syncytial virus; SCID, severe combined immunodeficiency; TMP-SMX, trimethoprim-sulfamethoxazole; VSV, varicella stomatitis virus; wk,weeks; y, years.

disease, and they also do not receive other vaccines, as they are receiving passive immunization through intravenous immunoglobulin (IVIG). Family members should also not receive live immunizations unless there is an outbreak of a specific infection in the community; however, routine immunization with inactivated influenza and pertussis should be continued owing to herd immunity. ${ }^{7}$

Gene therapy has been successfully used to treat SCID caused by mutations in the IL-2R $\gamma$ chain and ADA gene, especially in patients who lack a human leukocyte antigen (HLA)-identical sibling donor. ${ }^{53-55}$ Retroviral vectors containing copies of either the IL-2R $\gamma$ or ADA gene have been used to transduce stem cells. Although successful immune reconstitution was achieved, retrovirally induced activation of the LMO2 (LIM domain only 2 [rhombotin-like 1]) gene resulted in acute T-cell leukemia in several patients with ADA deficiency and IL-2R $\gamma$ deficiency. ${ }^{56,57}$ New gene therapy trials are in progress using vectors designed to prevent insertional mutagenesis.

\section{Conclusion and future directions}

The excitement generated by NBS for SCID has fostered new research into additional screening tests for other PIDs, including B-cell disorders. The B-cell kappa chain excision circle (KREC) assay, which is analogous to the TREC assay but for B-cells, has shown promise as an assay to detect infants with congenital agammaglobulinemia. ${ }^{58-60}$ Surely, as we better understand the molecular nature of PIDs, more NBS tests can be developed.
Because infants with SCID are being diagnosed prior to the onset of SCID-defining illness, the decision to perform HSCT can sometimes be difficult in the absence of a molecular diagnosis. This issue is particularly relevant in infants with sTCL who do not meet the conventional diagnosis of SCID. However, there is a consensus that definitive treatment for conventional SCID be performed even in the absence of a molecular diagnosis.

NBS for SCID with the TREC assay has been a resounding success in the US states in which it is currently being utilized..$^{8,40,42,43}$ Unfortunately, NBS for SCID has yet to expand to all 50 states, despite the fact that SCID was added to the Recommended Uniform Screening Panel of recommended NBS by the Health and Human Services Committee in May $2010 .{ }^{6}$ By expanding NBS, we may be able to understand the true incidence of SCID in the United States.

\section{Disclosure}

The authors report no conflicts of interest in this work.

\section{References}

1. Bonilla FA, Bernstein IL, Khan DA, et al; American Academy of Allergy, Asthma and Immunology; American College of Allergy, Asthma and Immunology; Joint Council of Allergy, Asthma and Immunology. Practice parameter for the diagnosis and management of primary immunodeficiency. Ann Allergy Asthma Immunol. 2005;94(5 Suppl 1): S1-S63.

2. Brown L, Xu-Bayford J, Allwood Z, et al. Neonatal diagnosis of severe combined immunodeficiency leads to significantly improved survival outcome: the case for newborn screening. Blood. 2011;117(11): $3243-3246$ 
3. Buckley RH. Molecular defects in human severe combined immunodeficiency and approaches to immune reconstitution. Annu Rev Immunol. 2004;22:625-655.

4. Myers LA, Patel DD, Puck JM, Buckley RH. Hematopoietic stem cell transplantation for severe combined immunodeficiency in the neonatal period leads to superior thymic output and improved survival. Blood. 2002;99(3):872-878.

5. Buckley RH, Schiff RI, Schiff SE, et al. Human severe combined immunodeficiency: genetic, phenotypic, and functional diversity in one hundred eight infants. J Pediatr. 1997;130(3):378-387.

6. Newborn Screening for Severe Combined Immunodeficiency Disorder. Secretary's Advisory Committee on Heritable Disorders in Newborns and Children; 2011. Available from: http://www.hrsa.gov/advisorycommittees/mchbadvisory/heritabledisorders/recommendations/correspondence/combinedimmunodeficiency.pdf. Accessed April 3, 2013.

7. Verbsky J, Thakar M, Routes J. The Wisconsin approach to newborn screening for severe combined immunodeficiency. J Allergy Clin Immunol. 2012;129(3):622-627.

8. Chase NM, Verbsky JW, Routes JM. Newborn screening for SCID: three years of experience. Ann NY Acad Sci. 2011;1238:99-105.

9. Stephan JL, Vlekova V, Le Deist F, et al. Severe combined immunodeficiency: a retrospective single-center study of clinical presentation and outcome in 117 patients. J Pediatr. 1993;123(4):564-572.

10. Leiva LE, Zelazco M, Oleastro M, et al; Latin American Group for Primary Immunodeficiency Diseases. Primary immunodeficiency diseases in Latin America: the second report of the LAGID registry. $J$ Clin Immunol. 2007;27(1):101-108.

11. Yee A, De Ravin SS, Elliott E, Ziegler JB; Contributors to the Australian Paediatric Surveillance Unit. Severe combined immunodeficiency: a national surveillance study. Pediatr Allergy Immunol. 2008;19(4):298-302.

12. Suliaman F, Al-Ghonaium A, Harfi H. High incidence of severe combined immune deficiency in the Eastern Province of Saudi Arabia. Pediatr Asthma Allergy Immunol. 2006;19(1):14-18.

13. Douek DC, Vescio RA, Betts MR, et al. Assessment of thymic output in adults after haematopoietic stem-cell transplantation and prediction of T-cell reconstitution. Lancet. 2000;355(9218):1875-1881.

14. Morinishi Y, Imai K, Nakagawa N, et al. Identification of severe combined immunodeficiency by T-cell receptor excision circles quantification using neonatal guthrie cards. J Pediatr. 2009;155(6): 829-833.

15. Routes JM, Grossman WJ, Verbsky J, et al. Statewide newborn screening for severe T-cell lymphopenia. JAMA. 2009;302(22):2465-2470.

16. Hale JE, Bonilla FA, Pai SY, et al. Identification of an infant with severe combined immunodeficiency by newborn screening. J Allergy Clin Immunol. 2010;126(5):1073-1074.

17. Cunningham-Rundles C, Ponda PP. Molecular defects in T- and B-cell primary immunodeficiency diseases. Nat Rev Immunol. 2005;5(11):880-892.

18. International Union of Immunological Societies Expert Committee on Primary Immunodeficiencies, Notarangelo LD, Fischer A, et al. Primary immunodeficiencies: 2009 update. J Allergy Clin Immunol. 2009;124(6):1161-1178.

19. Hirschhorn R. Adenosine deaminase deficiency: molecular basis and recent developments. Clin Immunol Immunopathol. 1995;76(3 Pt 2): S219-S227.

20. Puel A, Ziegler SF, Buckley RH, Leonard WJ. Defective IL7R expression in $\mathrm{T}(-) \mathrm{B}(+) \mathrm{NK}(+)$ severe combined immunodeficiency. Nat Genet. 1998;20(4):394-397.

21. Russell SM, Tayebi N, Nakajima H, et al. Mutation of Jak3 in a patient with SCID: essential role of Jak3 in lymphoid development. Science. 1995;270(5237):797-800

22. Macchi P, Villa A, Giliani S, et al. Mutations of Jak-3 gene in patients with autosomal severe combined immune deficiency (SCID). Nature. 1995;377(6544):65-68.

23. Schwarz K, Gauss GH, Ludwig L, et al. RAG mutations in human B cell-negative SCID. Science. 1996;274(5284):97-99.
24. Abe T, Tsuge I, Kamachi Y, et al. Evidence for defects in V(D)J rearrangements in patients with severe combined immunodeficiency. J Immunol. 1994;152(11):5504-5513.

25. Kalman L, Lindegren ML, Kobrynski L, et al. Mutations in genes required for T-cell development: IL7R, CD45, IL2RG, JAK3, RAG1, RAG2, ARTEMIS, and ADA and severe combined immunodeficiency: HuGE review. Genet Med. 2004;6(1):16-26.

26. Buckley RH. A historical review of bone marrow transplantation for immunodeficiencies. J Allergy Clin Immunol. 2004;113(4):793-800.

27. Villa A, Notarangelo LD, Roifman CM. Omenn syndrome: inflammation in leaky severe combined immunodeficiency. J Allergy Clin Immunol. 2008;122(6):1082-1086.

28. Griffith LM, Cowan MJ, Notarangelo LD, et al; Workshop Participants. Improving cellular therapy for primary immune deficiency diseases: recognition, diagnosis, and management. J Allergy Clin Immunol. 2009;124(6):1152-1160. e12.

29. Niehues T, Perez-Becker R, Schuetz C. More than just SCID - the phenotypic range of combined immunodeficiencies associated with mutations in the recombinase activating genes (RAG) 1 and 2. Clin Immunol. 2010;135(2):183-192.

30. Barron MA, Makhija M, Hagen LEM, Pencharz P, Grunebaum E, Roifman CM. Increased resting energy expenditure is associated with failure to thrive in infants with severe combined immunodeficiency. J Pediatr. 2011;159(4):628-632. e1.

31. Patel NC, Hertel PM, Estes MK, et al. Vaccine-acquired rotavirus in infants with severe combined immunodeficiency. $N$ Engl J Med. 2010;362(4):314-319.

32. Wilson JMG, Jungner G. Principles and Practice of Screening for Disease. Geneva: World Health Organization; 1968. Available from: http://apps.who.int/iris/bitstream/10665/37650/1/WHO_PHP_34.pdf. Accessed April 3, 2013.

33. Krishna MT, Tarrant JL, Cheadle EA, Noorani S, Hackett S, Huissoon AP. An audit of lymphopenia in infants under 3 months of age. Arch Dis Child. 2008;93(1):90-91.

34. Rosen FS. Severe combined immunodeficiency: a pediatric emergency. J Pediatr. 1997;130(3):345-346.

35. Puck JM; SCID Newborn Screening Working Group. Population-based newborn screening for severe combined immunodeficiency: steps toward implementation. J Allergy Clin Immunol. 2007;120(4):760-768.

36. McGhee SA, Stiehm ER, Cowan M, Krogstad P, McCabe ER. Two-tiered universal newborn screening strategy for severe combined immunodeficiency. Mol Genet Metab. 2005;86(4):427-430.

37. Janik DK, Lindau-Shepard B, Comeau AM, Pass KA. A multiplex immunoassay using the Guthrie specimen to detect T-cell deficiencies including severe combined immunodeficiency disease. Clin Chem. 2010;56(9):1460-1465.

38. Chan K, Puck JM. Development of population-based newborn screening for severe combined immunodeficiency. J Allergy Clin Immunol. 2005;115(2):391-398.

39. Baker MW, Grossman WJ, Laessig RH, et al. Development of a routine newborn screening protocol for severe combined immunodeficiency. J Allergy Clin Immunol. 2009;124(3):522-527.

40. Verbsky JW, Baker MW, Grossman WJ, et al. Newborn screening for severe combined immunodeficiency; the Wisconsin experience (2008-2011). J Clin Immunol. 2011;32(1):82-88.

41. Accetta D, Syverson G, Bonacci B, et al. Human phagocyte defect caused by a Rac2 mutation detected by means of neonatal screening for T-cell lymphopenia. J Allergy Clin Immunol. 2011;127(2):535-538. e1-e2.

42. Gerstel-Thompson JL, Wilkey JF, Baptiste JC, et al. High-throughput multiplexed T-cell-receptor excision circle quantitative PCR assay with internal controls for detection of severe combined immunodeficiency in population-based newborn screening. Clin Chem. 2010;56(9): 1466-1474.

43. Puck JM. Laboratory technology for population-based screening for severe combined immunodeficiency in neonates: the winner is T-cell receptor excision circles. J Allergy Clin Immunol. 2012;129(3): 607-616. 
44. Accetta DJ, Brokopp CD, Baker MW, Verbsky J, Routes JM. Cause of death in neonates with inconclusive or abnormal T-cell receptor excision circle assays on newborn screening. J Clin Immunol. 2011;31(6): 962-967.

45. Chabra S, Cottrill C, Rayens MK, Cross R, Lipke D, Bruce M. Lymphocyte subsets in cord blood of preterm infants: effect of antenatal steroids. Biol Neonate. 1998;74(3):200-207.

46. Holodniy M, Kim S, Katzenstein D, Konrad M, Groves E, Merigan TC. Inhibition of human immunodeficiency virus gene amplification by heparin. J Clin Microbiol. 1991;29(4):676-679.

47. Watkinson SJ, Lee CC, Steer CV. Delivery of a baby with severe combined immunodeficiency at 31 weeks gestation following an extreme preterm prelabour spontaneous rupture of the membranes: a case report. J Med Case Rep. 2009;3:118.

48. Müller SM, Ege M, Pottharst A, Schulz AS, Schwarz K, Friedrich W. Transplacentally acquired maternal $\mathrm{T}$ lymphocytes in severe combined immunodeficiency: a study of 121 patients. Blood. 2001;98(6):1847-1851.

49. Stiehm RE, Ochs HD, Winkelstein JA. Immunologic Disorders in Infants and Children. 5th ed. Philadelphia, PA: WB Saunders; 2004.

50. Buckley RH. Transplantation of hematopoietic stem cells in human severe combined immunodeficiency: longterm outcomes. Immunol Res. 2010;49(1-3):25-43.

51. Antoine C, Müller S, Cant A, et al; European Group for Blood and Marrow Transplantation; European Society for Immunodeficiency. Long-term survival and transplantation of haemopoietic stem cells for immunodeficiencies: report of the European experience 1968-1999. Lancet. 2003;361(9357):553-560.
52. Railey MD, Lokhnygina Y, Buckley RH. Long-term clinical outcome of patients with severe combined immunodeficiency who received related donor bone marrow transplants without pretransplant chemotherapy or post-transplant GVHD prophylaxis. J Pediatr. 2009;155(6): 834-840.e1.

53. Fischer A, Hacein-Bey-Abina S, Cavazzana-Calvo M. Gene therapy for primary adaptive immune deficiencies. J Allergy Clin Immunol. 2011;127(6):1356-1359.

54. Cavazzana-Calvo M, Hacein-Bey S, de Saint Basile G, et al. Gene therapy of human severe combined immunodeficiency (SCID)-X1 disease. Science. 2000;288(5466):669-672.

55. Cavazzana-Calvo M, Fischer A, Hacein-Bey-Abina S, Aiuti A. Gene therapy for primary immunodeficiencies: Part 1. Curr Opin Immunol. 2012;24(5):580-584.

56. McCormack MP, Rabbitts TH. Activation of the T-cell oncogene LMO2 after gene therapy for X-linked severe combined immunodeficiency. N Engl J Med. 2004;350(9):913-922.

57. Woods NB, Bottero V, Schmidt M, von Kalle C, Verma IM. Gene therapy: therapeutic gene causing lymphoma. Nature. 2006; 440(7088):1123.

58. van Zelm MC, van der Burg M, Langerak AW, van Dongen JJM. PID comes full circle: applications of V(D)J recombination excision circles in research, diagnostics and newborn screening of primary immunodeficiency disorders. Front Immunol. 2011;2:12.

59. Chinen J, Notarangelo LD, Shearer WT. Advances in basic and clinical immunology in 2012. J Allergy Clin Immunol. 2013;131(3):675-682.

60. Borte S, von Döbeln U, Fasth A, et al. Neonatal screening for severe primary immunodeficiency diseases using high-throughput triplex real-time PCR. Blood. 2012;119(11):2552-2555.
Clinical Epidemiology

\section{Publish your work in this journal}

Clinical Epidemiology is an international, peer-reviewed, open access journal focusing on disease and drug epidemiology, identification of risk factors and screening procedures to develop optimal preventative initiatives and programs. Specific topics include: diagnosis, prognosis, treatment, screening, prevention, risk factor modification, systematic

\section{Dovepress}

reviews, risk \& safety of medical interventions, epidemiology \& biostatical methods, evaluation of guidelines, translational medicine, health policies \& economic evaluations. The manuscript management system is completely online and includes a very quick and fair peer-review system, which is all easy to use. 